\title{
Recovery of copper and lead from waste printed circuit boards by supercritical water oxidation combined with electrokinetic process
}

\author{
Fu-Rong Xiu ${ }^{\mathrm{a}, \mathrm{b}}$, Fu-Shen Zhang a,* \\ a Research Center for Eco-Environmental Sciences, Chinese Academy of Sciences, 18 Shuangqing Road, Beijing 100085, China \\ ${ }^{\mathrm{b}}$ Graduate University of Chinese Academy of Sciences, Beijing 100039, China
}

\section{A R T I C L E I N F O}

\section{Article history:}

Received 5 June 2008

Received in revised form 3 October 2008

Accepted 20 October 2008

Available online 31 October 2008

\section{Keywords:}

Heavy metal

PCBs

Supercritical oxidation

Electrokinetics

Waste electric and electronic equipments

\begin{abstract}
A B S T R A C T
An effective and benign process for copper and lead recovery from waste printed circuit boards (PCBs) was developed. In the process, the PCBs was pre-treated in supercritical water, then subjected to electrokinetic (EK) process. Experimental results showed that supercritical water oxidation (SCWO) process was strong enough to decompose the organic compounds of PCBs, and XRD spectra indicated that copper and lead were oxidized into $\mathrm{CuO}, \mathrm{Cu}_{2} \mathrm{O}$ and $\beta-\mathrm{PbO}_{2}$ in the process. The optimum SCWO treatment conditions were $60 \mathrm{~min}, 713 \mathrm{~K}, 30 \mathrm{MPa}$, and EK treatment time, constant current density were $11 \mathrm{~h}, 20 \mathrm{mAcm}^{-2}$, respectively. The recovery percentages of copper and lead under optimum SCWO + EK treatment conditions were around $84.2 \%$ and $89.4 \%$, respectively. In the optimized EK treatment, $74 \%$ of $\mathrm{Cu}$ was recovered as a deposit on the cathode with a purity of $97.6 \%$, while $\mathrm{Pb}$ was recovered as concentrated solutions in either anode (23.1\%) or cathode (66.3\%) compartments but little was deposited on the electrodes. It is believed that the process is effective and practical for $\mathrm{Cu}$ and $\mathrm{Pb}$ recovery from waste electric and electronic equipments.
\end{abstract}

(c) 2008 Elsevier B.V. All rights reserved.

\section{Introduction}

Printed circuit boards (PCBs) are widely used in many electrical and electronic equipments such as household appliances, computers, etc. It is estimated that as many as $\mathbf{5 0 0}$ million personal computers (PCs) have become obsolete and enter the municipal solid waste stream between 2000 and 2007 [1]. Waste PCBs are particularly difficult to dispose because of the heterogeneous mix of polymer materials, multiple kinds of metals, and glass fiber. Currently, waste PCBs are either incinerated, which can lead to the formation of toxic atmospheric pollution through the release of dioxins and furans [2], or sent to landfill, which can lead to toxic matter such as heavy metal $\mathrm{Pb}$ (around 2\% in PCBs) leaching into the groundwater. Previous study [3], using the toxicity characteristic leaching procedure (TCLP) of the US Environmental Protection Agency (USEPA), has shown that $\mathrm{Pb}$ concentrations in the extracts of a vast majority of the PCBs are higher than the limit levels. On the other hand, the quantity of valuable metals, especially $\mathrm{Cu}$ (around $20 \%$ in PCBs), turns the wastes into an interesting raw material from the economic point of view. Therefore, it is of great importance to develop effective and environmental benign processes for treatment of these types of wastes so as to recover the valuable matters and simultaneously remove the toxic substances.

\footnotetext{
* Corresponding author. Tel.: +86 10 62849515; fax: +86 1062849515 .

E-mail addresses: fszhang@rcees.ac.cn, frxiu_st@rcees.ac.cn (F.-S. Zhang).
}

In recent years, supercritical water oxidation (SCWO) technique has been widely applied to the process of decomposition of stable toxic organic wastes [4,5]. At supercritical conditions $(T>647.3 \mathrm{~K}$, $P>22.1 \mathrm{MPa}$ ), water has a high solubility for both organics and oxygen, and organic compounds, oxygen, and water form a single and homogeneous phase, which allows oxidation to proceed rapidly by an elimination of the potential interface mass transport limitations $[6,7]$. Recently, this technique has been successfully applied to the degradation of waste polymer materials $[8,9]$. Polymers could be degraded and recovered as monomers or low molecular weight organic compounds in a very short residence time in supercritical water without causing air pollution [9]. Recently, it has been reported that polymers in waste PCBs could be degraded into $\mathrm{CO}_{2}$ and $\mathrm{H}_{2} \mathrm{O}$ in the SCWO process, and the formation of brominated polycyclic aromatic hydrocarbons (PAHs) was eliminated at the same time [10]. Thus far, many studies on the application of SCWO have focused on the removal or recovery of organic substances for wastes treatment, only a little information is available on the behavior of the metallic elements in the process. Lately, Fang et al. [11] reported the behavior of some heavy metals during oxidation of industrial wastes in supercritical water. It also has been reported [10] that copper $(\mathrm{Cu})$ in waste PCBs can be oxidized to oxides during SCWO treatment. However, little is known about the behavior of $\mathrm{Pb}$, one of the most significant heavy metals in waste PCBs, during SCWO process.

For many years, electrokinetic processes (EK) have been widely investigated and applied in soil and groundwater remediation 
[12-13]. The method uses direct current as the "cleaning agent", combining the electrokinetic movement of ions in the matrix. Recently, some researchers [14-21] reported the use of such techniques for metal recovery or removal from solid wastes, and more lately, Guillaume et al. [22] reported an effective EK process which combines electroleaching and electrodeposition in a single-cell to recover zinc from some zinc-rich solid wastes, without transportation of solids or fluids from one chamber to another by pumps or other mechanical processes, and the principle of which has been well described. This achievement induced us to test the process for the treatment of SCWO-treated PCBs particles, and evaluate the feasibility of the application of such process to recover or remove metallic elements from waste PCBs that contain large numbers of $\mathrm{Cu}$ and $\mathrm{Pb}$.

In this study, we attempted to develop a highly efficient and benign process for copper and lead recovery from waste PCBs. The integrated process combined SCWO and EK techniques in the treatment of PCBs. The SCWO process was used as a pre-treatment to degrade the polymers and oxidize copper and lead in waste PCBs. The EK process relied upon application of an electric field to the SCWO-treated PCBs, and metal ions or ionic complexes are formed and migrate to the cathode or anode, and form enriched solutions or reduce to form a deposit on the cathode.

\section{Materials and methods}

\subsection{SCWO experiments}

Waste PCBs used in this work were supplied by HUAXING Environment Protection Company of Beijing. After the components (relays, capacitors, etc.) were disassembled, the PCBs were sent to comminute in a cutting mill until the fractions reached particle size smaller than $0.1 \mathrm{~mm}$. All chemicals were purchased from Chemical Reagent Company of Beijing in analytical grade.

In the SCWO treatment experiments, $10 \mathrm{~g}$ of the sample and $50 \mathrm{ml}$ of distilled water were employed, while hydrogen peroxide $\left(\mathrm{H}_{2} \mathrm{O}_{2}, 30 \mathrm{wt}\right.$ \% $)$ was used as oxygen source. Experiments were conducted in a 200-ml high-pressure reactor made of 316 alloy. Referring to a previous report [10], $713 \mathrm{~K}$ and $30 \mathrm{MPa}$ was selected for SCWO treatment, since most of the polymer in PCBs could be decomposed to $\mathrm{CO}_{2}$ and $\mathrm{H}_{2} \mathrm{O}$ at foregoing conditions. Six SCWO treatments were performed with treatment time of 15, 30, 60, 90, 120 and 150 min, respectively. Metal content in the raw PCBs and in the SCWO treatment residues were measured by ICP-OES after aqua regia digestion [23]. $\mathrm{Cu}$ and $\mathrm{Pb}$ concentrations in the solutions after SCWO treatments were also measured by ICP-OES and the $\mathrm{pH}$ of the solutions were measured by Radiometer Analytical pH electrode. Organic matter weight of the initial PCBs and the SCWO-treated PCBs were determined by loss of ignition at $550^{\circ} \mathrm{C}$ for $1 \mathrm{~h}$.

\subsection{EK experiments}

Fig. 1 shows a schematic drawing of the EK setup. After each SCWO treatment, the suspension obtained was filtrated using a vacuum filter and $2 \mathrm{~g}$ of the residue was transferred into compartment II of EK cell after dryness, while $20 \mathrm{ml}$ of $\mathrm{HCl}(1 \mathrm{M})$ solutions were added. The SCWO-treated PCBs was kept in the suspension by constant stirring $(1600 \mathrm{rpm})$ with magnetic stirrer (SH-3 from JBD, Beijing, China). The anolyte and catholyte were separated by two porous glass frits with $1 \mathrm{~mm}$ thickness and pore size below $50 \mu \mathrm{m}$. Platinum-coated electrodes from LEICI (Shanghai, China) were used as working electrodes. The electrodes were plates with an active area of $2 \mathrm{~cm}^{2}$, and the power supply was a TPR-6405D (LONGWEI, H.K). Either anolyte or catholyte initially consisted of $20 \mathrm{ml} 1 \mathrm{M} \mathrm{HCl}$ without adjusting all along the

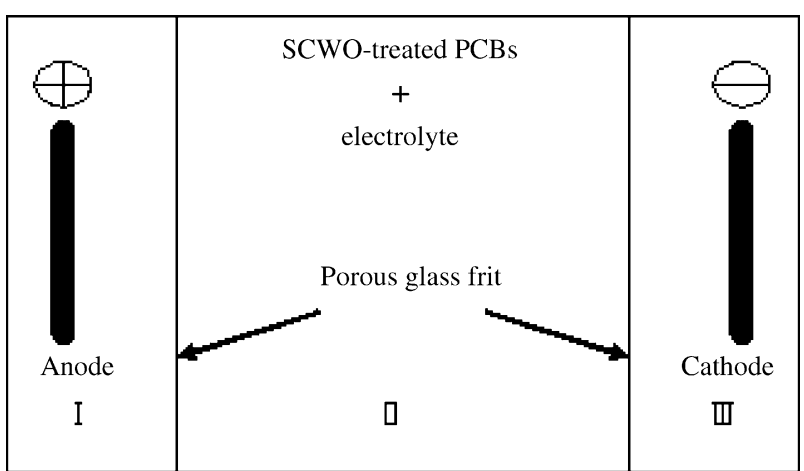

Fig. 1. Schematic drawing of the EK setup.

experiment. The constant current density was $10,20,30 \mathrm{~mA} / \mathrm{cm}^{2}$, respectively.

After each EK experiment, electrodes were dipped in $5 \mathrm{M} \mathrm{HNO}_{3}$ overnight. Volumes of the cleaning acids and the electrolytes were measured followed by analysis of the metal concentrations by ICPOES.

The structure of the PCB solid residue after SCWO treatment and deposits on the cathodes after EK process were characterized by Xray diffraction spectroscopy (XRD) at $50 \mathrm{kV}$ and $100 \mathrm{~mA}$ using $\mathrm{Cu}$ $\mathrm{K} \alpha$ radiation $(\lambda=1.5418 \AA)$. Chemical composition of the deposits obtained on the cathodes was determined by X-ray fluorescence (XRF).

\section{Results and discussion}

\subsection{Effect of SCWO treatment on $\mathrm{Cu}, \mathrm{Pb}$ species and organic compounds}

For understanding the species of $\mathrm{Cu}$ and $\mathrm{Pb}$ after SCWO process, crystal properties of the solid residue from $1 \mathrm{~h}$ SCWO-treated PCBs was studied by X-ray diffraction spectroscopy. Fig. 2 shows clearly that $\mathrm{CuO}, \mathrm{Cu}_{2} \mathrm{O}$ are the main species in the solid residue, in agreement with a previous report that $\mathrm{CuO}, \mathrm{Cu}_{2} \mathrm{O}$ and $\mathrm{Cu}(\mathrm{OH})_{2}$ are the main products in PCBs residue in the presence of $\mathrm{NaOH}$ after SCWO treatment [10]. It can be seen in Fig. 2 that $\mathrm{PbO}_{2}$ is the preponderant specie of $\mathrm{Pb}$ in the solid residue. The peaks at $2 \theta$ of $25.3,32.2$ and 49.2 indicate the forming of $\beta-\mathrm{PbO}_{2}$. This could be attributed to the complete oxidation of $\mathrm{Pb}$, whereas copper may not be oxidized completely in the SCWO process [10]. $\mathrm{Cu}(0)$ and $\mathrm{Pb}(0)$ species could not be observed in the XRD pattern indicating the entire oxidation of $\mathrm{Cu}(0)$ and $\mathrm{Pb}(0)$.

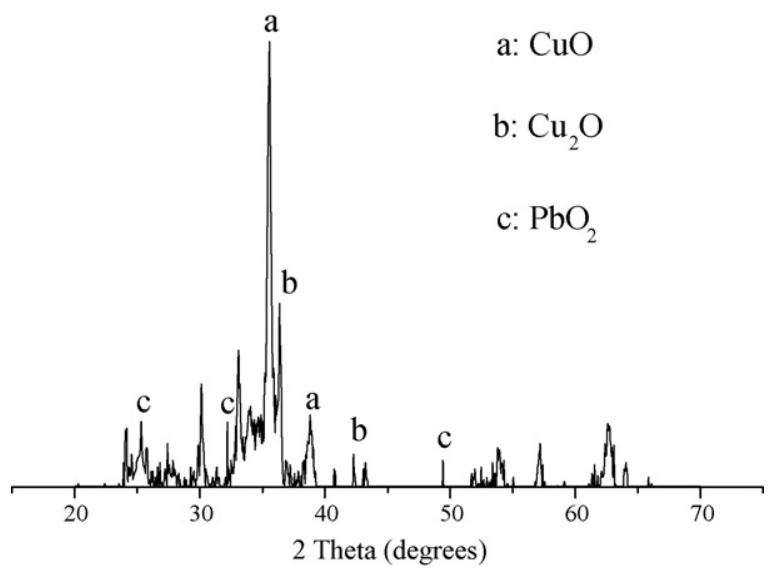

Fig. 2. X-ray diffraction patterns of the solid residue from $1 \mathrm{~h} \mathrm{SCWO-treated} \mathrm{PCBs.}$ 


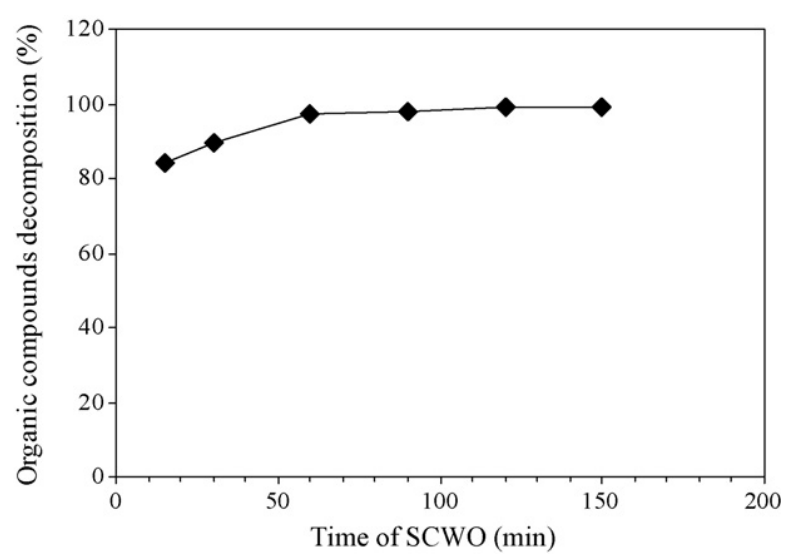

Fig. 3. Effect of SCWO treatment time on organic compounds decomposition.

Effect of SCWO treatment on organic compounds decomposition is shown in Fig. 3. Organic compounds decomposition is expressed as

organic compounds decomposition (\%) $=\frac{M_{1}-M_{2}}{M_{1}} \times 100$

where $M_{1}$ is the organic matter weight of the initial PCBs and $M_{2}$ the organic matter weight of the SCWO-treated PCBs. Organic compounds decomposition of waste PCBs increased with the increase of SCWO treatment time, and the organic compounds decomposition at $713 \mathrm{~K}, 30 \mathrm{MPa}$ and $1 \mathrm{~h} \mathrm{SCWO}$ treatment was $97.8 \%$. The supercritical water exhibited a unique characteristic of a slightly polar organic solvent. Therefore, organics and oxygen became completely miscible in supercritical water [10]. The results showed that organic compounds in the waste PCBs were oxidized very effectively in supercritical water.

Therefore, it is believed that $1 \mathrm{~h}$ SCWO treatment is sufficient for the pre-treatment.

\subsection{Mass balance of $\mathrm{Cu}$ and $\mathrm{Pb}$ in the SCWO process}

Table 1 presents the mass balance of $\mathrm{Cu}$ and $\mathrm{Pb}$ in the six treatments. The definition of metal recovery yield in residue after SCWO process is expressed as

metal recovery yield in residue (\%)

$$
=\frac{\text { metal content in PCBs residue after SCWO }}{\text { initial metal content in PCBS }} \times 100
$$

It can been seen that $\mathrm{Cu}$ recovery yield in the residue after SCWO increased with the treatment time during the first $60 \mathrm{~min}$ but decreased thereafter, and reached a steady level after $90 \mathrm{~min}$. This could be attributed to the variation of the $\mathrm{pH}$ in the system in different SCWO treatment time. It can be seen in Fig. 4 that the effect of SCWO treatment time on the $\mathrm{pH}$ of the system. One inter-

Table 1

Mass balance of $\mathrm{Cu}$ and $\mathrm{Pb}$ in different SCWO treatments.

\begin{tabular}{lccllll}
\hline \multicolumn{7}{c}{ SCWO time (min) } \\
\cline { 2 - 7 } & 15 & 30 & 60 & 90 & 120 & 150 \\
\hline Cu1 (\%) & 94.0 & 95.1 & 99.8 & 97.4 & 96.5 & 96.5 \\
Cu2 (mg) & 120.1 & 97.55 & 3.65 & 52.52 & 71.4 & 71.3 \\
Pb1 (\%) & 98.9 & 100 & 102 & 99.6 & 101 & 103 \\
Pb2 (mg) & 0.2 & 0.1 & n.d. & n.d. & 0.05 & n.d. \\
\hline
\end{tabular}

1: metal recovery yield in residue after SCWO; 2 : metal content in filtrate after SCWO; n.d.: non-detectable.

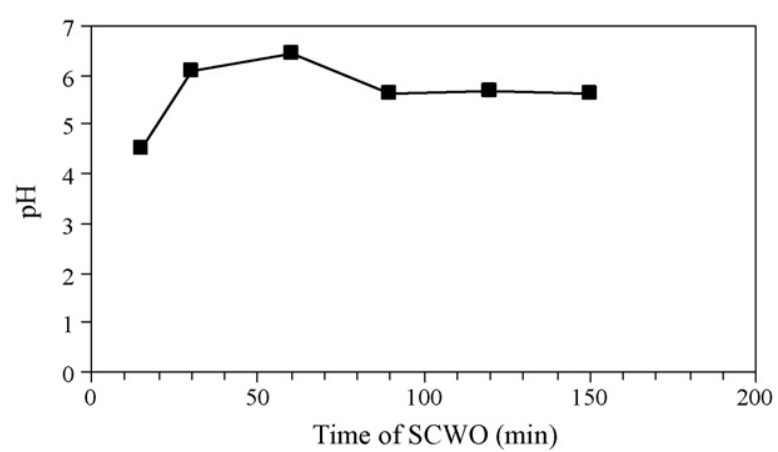

Fig. 4. Effect of SCWO treatment time on $\mathrm{pH}$ values.

esting result from Fig. 4 and Table 1 is that the variation trend of the system $\mathrm{pH}$ consistent with that of $\mathrm{Cu}$ recovery yield in residue. The highest $\mathrm{Cu}$ recovery yield in the residue and the highest solution $\mathrm{pH}$ were all obtained at $1 \mathrm{~h}$ SCWO treatment, and moreover, the least loss of $\mathrm{Cu}(3.65 \mathrm{mg})$ in the filtrate was also at this point. All of the foregoing results could be attributed to the higher $\mathrm{pH}$ of the system, leading to the less dissolution of the solid phase such as the metal oxides. One possible reason for the variation of the system $\mathrm{pH}$ was the degradation of the polymer in PCBs during the SCWO process. At the first stage (about 15 min of SCWO treatment), the polymer (mainly epoxy resin) in the PCB wastes decomposed to lower molecular organic compounds rapidly and produce many organic acids and $\mathrm{CO}_{2}$ [24]. Thus the produced organic acids and $\mathrm{CO}_{2}$ could lead to the low $\mathrm{pH}$ of the system and the increase of the dissolution of the metal oxides. In addition, Br species in waste PCBs exist as $\mathrm{H}^{+}+\mathrm{Br}^{-}$in water after the SCWO process [10]. After the first stage, $\mathrm{pH}$ increased when $\mathrm{Br}^{-}$was oxidized to $\mathrm{Br}_{2}$ along with the increase of time and the organic acids decreased due to the complete oxidation of the organic acids to $\mathrm{CO}_{2}$ and $\mathrm{H}_{2} \mathrm{O}$. The maximal recovery yield of $\mathrm{Cu}$ in the residue (about 99.8\%) was obtained at $60 \mathrm{~min}$, while the $\mathrm{pH}$ value of the system was the highest (6.5) at this point. Subsequently, more $\mathrm{CO}_{2}$ that was produced from the complete oxidation of the organic acids dissolved in the system, leading to the decline of the $\mathrm{pH}$ and the dissolution of the solid phase. But the $\mathrm{pH}$ reached a steady level after $90 \mathrm{~min}$, which could be attributed to the dissolution equilibrium of $\mathrm{CO}_{2}$ in the system.

It can also be seen from Table 1 that the recovery of $\mathrm{Pb}$ approached $100 \%$ after 15 min SCWO treatment, thus it can be concluded that the effect of SCWO treatment time on the recovery of $\mathrm{Pb}$ in this process is negligible. Accordingly, from both economic and efficiency point of view, 60 min SCWO-treated PCBs was used in the following EK experiments.

\subsection{Migration of $\mathrm{Cu}$ and $\mathrm{Pb}$ in the EK process}

Figs. 5 and 6 illustrate the recovery of $\mathrm{Cu}$ and $\mathrm{Pb}$ in the anodic or cathodic compartments at different EK treatment times. The metal recovery yield was expressed as

metal recovery yield $(\%)=\frac{M}{\text { initial metal content in PCBs }} \times 100$

where $M$ is the content of metal ( $\mathrm{Cu}$ or $\mathrm{Pb}$ ) in anode compartment, cathode compartment, or deposited on cathode.

The recovery of $\mathrm{Cu}$ in the anodic compartment was negligible, mainly attributing to the diffusion throughout the glass frit. Most of $\mathrm{Cu}$ was recovered in cathodic compartment or deposited on cathode. The recovery of $\mathrm{Pb}$ in anodic or cathodic compartment was increased along with the increase of EK time. 


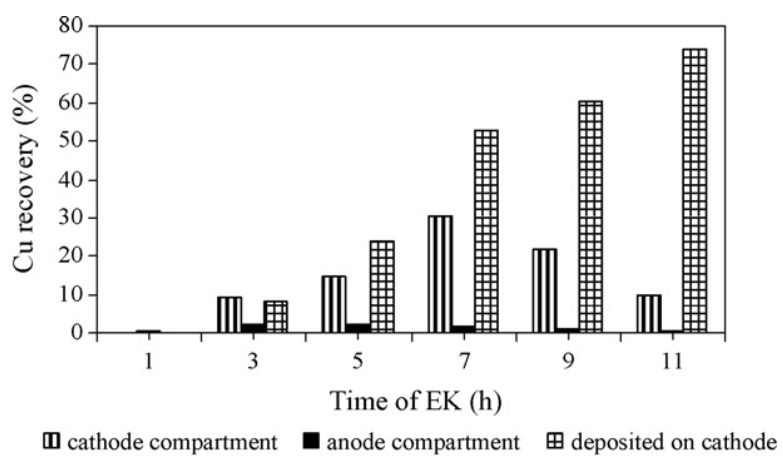

Fig. 5. Effect of EK time on the recovery of $\mathrm{Cu}$ in anode and cathode compartments (current density: $20 \mathrm{~mA} / \mathrm{cm}^{2}$ ).

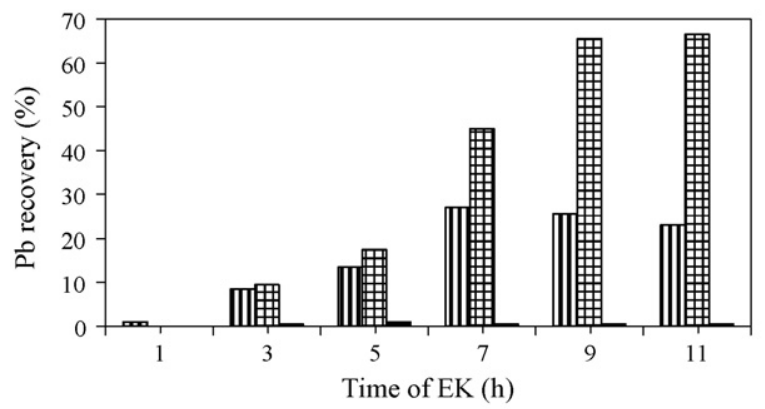

W anode compartment $\mathbf{⿴ 囗 十}$ cathode compartment $\mathbf{D}$ deposited on cathode

Fig. 6. Effect of EK time on the recovery of $\mathrm{Pb}$ in anode and cathode compartments (current density: $20 \mathrm{~mA} / \mathrm{cm}^{2}$ ).

$\mathrm{Cu}$ and $\mathrm{Pb}$ can form complexes with $\mathrm{Cl}^{-}$and the complexes can be positive, negative or uncharged $\left(\mathrm{MeCl}^{+}, \mathrm{MeCl}_{2}\right.$ (aq), $\mathrm{MeCl}_{3}{ }^{-}$and $\mathrm{MeCl}_{4}{ }^{2-}$ ), especially $\mathrm{Pb}$ form stable complexes with $\mathrm{Cl}^{-}$[25].

Since most $\mathrm{Cu}$ moved as cations, free $\mathrm{Cu}$ ion and $\mathrm{CuCl}^{+}$dominated in the solution. $\mathrm{Pb}$ moved towards both cathode and anode compartments during the EK process, indicating both positively $\left(\mathrm{Pb}^{2+}\right.$ and $\left.\mathrm{PbCl}^{+}\right)$and negatively $\left(\mathrm{PbCl}^{3-}\right.$ and $\left.\mathrm{PbCl}_{4}{ }^{2-}\right)$ charged $\mathrm{Pb}$ species existed in the solution. The formation of dissolved heavy metal complexes could increase the solubility and the mobility of the metal in the EK process [26].

In the EK process, lead oxides $\left(\mathrm{PbO}_{2}\right)$ dissolved in compartment II and produced high valence lead ions such as $\mathrm{Pb}^{4+}$, which was unstable in $\mathrm{HCl}$ system and could be reduced to low valence lead ions such as $\mathrm{Pb}^{2+}$ by $\mathrm{Cl}^{-}$or $\mathrm{Cu}^{+}$because the standard reduction potential $\left(E^{0}\right)$ of $\mathrm{PbO}_{2} / \mathrm{Pb}^{2+}, 1.455 \mathrm{~V}$, is larger than that of $\mathrm{Cl}_{2} / \mathrm{Cl}^{-}$, $1.36 \mathrm{~V}$, and $\mathrm{Cu}^{2+} / \mathrm{Cu}^{+}, 0.153 \mathrm{~V}$, then the $\mathrm{Pb}^{2+}$ formed chlorocomplexes of lead such as $\mathrm{PbCl}_{3}{ }^{-}$or $\mathrm{PbCl}_{4}{ }^{2-}$ and moved towards anode. Another possible route for the forming of $\mathrm{PbCl}_{3}{ }^{-}$or $\mathrm{PbCl}_{4}{ }^{2-}$ is that high valence lead ions moved to cathode in the electric field and were reduced to low valence lead ions near the cathode, then chlorocomplexes of lead formed and migrated to anode in the electric field. All these resulted in the decrease of the content of lead species in the liquid of compartment II, which could break the fol- lowing chemical reaction equilibriums:

$$
\begin{aligned}
& \mathrm{PbO}_{2}+4 \mathrm{H}^{+}+2 \mathrm{e}=\mathrm{Pb}^{2+}+2 \mathrm{H}_{2} \mathrm{O} \\
& 4 \mathrm{~Pb}^{2+}+n \mathrm{Cl}^{-}=\mathrm{PbCl}^{+}+\mathrm{PbCl}_{2}(\mathrm{aq})+\mathrm{PbCl}_{3}{ }^{-}+\mathrm{PbCl}_{4}{ }^{2-}
\end{aligned}
$$

Accordingly, the reactions (4) and (5) move towards right, and more lead dissolved, forming more ions or chloride complexes that move towards cathode or anode. One interesting result from Fig. 6 is that the recovery of $\mathrm{Pb}$ in the anode compartment after $7 \mathrm{~h}$ treatment decreased to a certain degree, which could be attributed to the oxidation of $\mathrm{Cl}^{-}$near the anode and the conversion of some $\mathrm{Pb}$ from negative complexes to positive complexes or free ions. The smell of chlorine gas was noticed near the anode after $5 \mathrm{~h}$ EK treatment.

\subsection{Effect of current density on total recovery yield of $\mathrm{Cu}$ and $\mathrm{Pb}$ in EK process}

The effect of current density on total recovery yield of $\mathrm{Cu}$ and $\mathrm{Pb}$ in EK process is shown in Table 2. Total metal recovery yield was calculated as follows:

total metal recovery yield $(\%)=\frac{\text { summation }}{\text { initial metal content in } \mathrm{PCBs}} \times 100$

where summation is the total amount of metal found in the electrolytes (except compartment II) and electrodes after each experiment.

Current efficiency was determined as the ratio of the weight of copper $W_{1}$ deposited on the cathode with electrical quantity $Q$, to the theoretical weight of deposited metal $W_{2}$ calculated by using Faraday's law:

$W_{2}=\frac{M_{\mathrm{Cu}} Q}{Z_{\mathrm{Cu}} F}$

where $F$ is the Faraday's constant, $M_{\mathrm{Cu}}$ the molar weight of copper $\left(63.54 \mathrm{~g} \mathrm{~mol}^{-1}\right)$, and $Z_{\mathrm{Cu}}$ is the valence of copper, i.e. 2. $Q$ (electric quantity) is the product of the applied current $I$ and the period of time, $t$. Eq. (8) gives the current efficiency (CE):

$\mathrm{CE}(\%)=\frac{W_{1}}{W_{2}} \times 100$

The total recovery yield of $\mathrm{Cu}$ and $\mathrm{Pb}$ at $11 \mathrm{~h}$ EK treatment increased with the increase of applied current density, and the higher current density applied, the higher initial potential gradient was observed (Table 2). Although the highest total recovery yield of $\mathrm{Cu}$ and $\mathrm{Pb}$ were all obtained when $30 \mathrm{~mA} / \mathrm{cm}^{2}$ current density was applied, it is too high energy consumption and not economic due to the too low current efficiency, $51 \%$. The reason for the low CE is that the increase of potential gradient could result in much more side reactions such as the reduction of $\mathrm{H}^{+}$on the cathode. The $20 \mathrm{~mA} / \mathrm{cm}^{2}$ current density was applied in the optimized EK treatment because the relatively high total recovery yield of $\mathrm{Cu}, \mathrm{Pb}$ and current efficiency could be obtained at the same time.

Variation of potential gradient during EK process (current density $=20 \mathrm{~mA} / \mathrm{cm}^{2}$ ) was shown in Fig. 7. During the first $80 \mathrm{~min}$, the potential gradient increased rapidly which could be attributed

Table 2

\begin{tabular}{|c|c|c|c|c|c|}
\hline $\mathrm{CD}\left(\mathrm{mA} / \mathrm{cm}^{2}\right)$ & $\mathrm{PG}(\mathrm{i})(\mathrm{V} / \mathrm{cm})$ & $\mathrm{PG}(\mathrm{e})(\mathrm{V} / \mathrm{cm})$ & Cu total recovery (\%) & $\mathrm{Pb}$ total recovery $(\%)$ & $\mathrm{CE}(\%)$ \\
\hline 10 & 0.24 & 0.37 & 66.3 & 72.7 & 84 \\
\hline 20 & 0.35 & 0.53 & 84.2 & 89.4 & 70 \\
\hline 30 & 0.42 & 0.89 & 92.1 & 93.5 & 51 \\
\hline
\end{tabular}

Effect of current density on total recovery yield of $\mathrm{Cu}$ and $\mathrm{Pb}$ in EK process.

EK time: 11 h; CD: current density; CE: current efficiency; PG(i): initial potential gradient; PG(e): potential gradient in the end. 


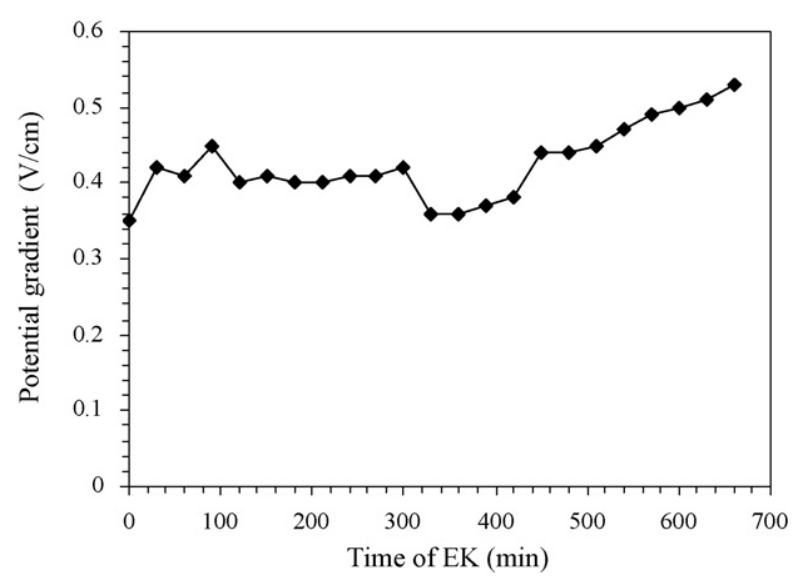

Fig. 7. Variation of potential gradient in EK process (current density: $20 \mathrm{~mA} / \mathrm{cm}^{2}$ ).

to the rapid decrease of $\mathrm{H}^{+}$and the too low metals ions concentration in solution. After this first period, the potential gradient decreased with the increase of EK time, especially after the $300 \mathrm{~min}$ EK treatment, the potential gradient decreased quickly, which was consistent with the migration result of $\mathrm{Cu}$ ions (Fig. 5). It can be seen in Fig. 5 that the content of $\mathrm{Cu}$ ions increased rapidly after $5 \mathrm{~h}$ EK treatment, which was favorable to decrease the potential gradient. This means that the electro-leaching efficiency of metals species was higher during this period. After $8 \mathrm{~h}$ EK treatment, the potential gradient increased again due to the decrease of the concentrations of $\mathrm{H}^{+}$and $\mathrm{Cu}$ ions.

\subsection{Effect of time on total recovery yield of $\mathrm{Cu}$ and $\mathrm{Pb}$ in $\mathrm{EK}$ process}

Figs. 9 and 10 illustrate the effect of time on total recovery yield of $\mathrm{Cu}$ and $\mathrm{Pb}$ in EK experiments, and the purity and crystal properties of $\mathrm{Cu}$ deposited on cathode are presented in Table 3 and Fig. 8, respectively. It can be seen in Fig. 5 that the recovery yield of $\mathrm{Cu}$ in compartment III (except the deposition) increased with the increase of EK processing time during the first $7 \mathrm{~h}$ and decreased thereafter. It can also be observed in Fig. 5 that little $\mathrm{Cu}$ deposited on the cathode in the first $3 \mathrm{~h}$ during the EK process, which could be attributed to the low $\mathrm{Cu}$ ion concentration in compartment III and the high $\mathrm{H}^{+}$that could be reduced on the cathode, but $\mathrm{Cu}$ deposited on cathode increased quickly after $3 \mathrm{~h}$, e.g., Cu deposition percentage increased about two times at $7 \mathrm{~h}$ compared to $5 \mathrm{~h}$, which could be attributed to the highest $\mathrm{Cu}$ ions concentration in III compartment (Fig. 5). In such three-compartment EK system, a higher metal ion concentration in cathode compartment could allow a higher amount of deposited metal, with higher current efficiency [22].

It can be seen from Figs. 9 and 10 that about $84.2 \%$ of $\mathrm{Cu}$ in the waste PCBs was recovered while $74 \%$ deposited on the cathode after

Table 3

Chemical composition of the cathode deposit analyzed by X-ray fluorescence.

\begin{tabular}{lc}
\hline & Wt.\% \\
\hline $\mathrm{Cu}$ & 97.6 \\
$\mathrm{~Pb}$ & 1.08 \\
$\mathrm{Sn}$ & 0.62 \\
$\mathrm{Fe}$ & 0.33 \\
$\mathrm{Zn}$ & 0.25 \\
$\mathrm{As}$ & 0.01 \\
$\mathrm{Ni}$ & 0.04 \\
$\mathrm{Cd}$ & 0.02 \\
$\mathrm{Cr}$ & 0.01 \\
\hline
\end{tabular}

EK parameter: $20 \mathrm{~mA} / \mathrm{cm}^{2}$ constant current density, $11 \mathrm{~h}$ treatment.

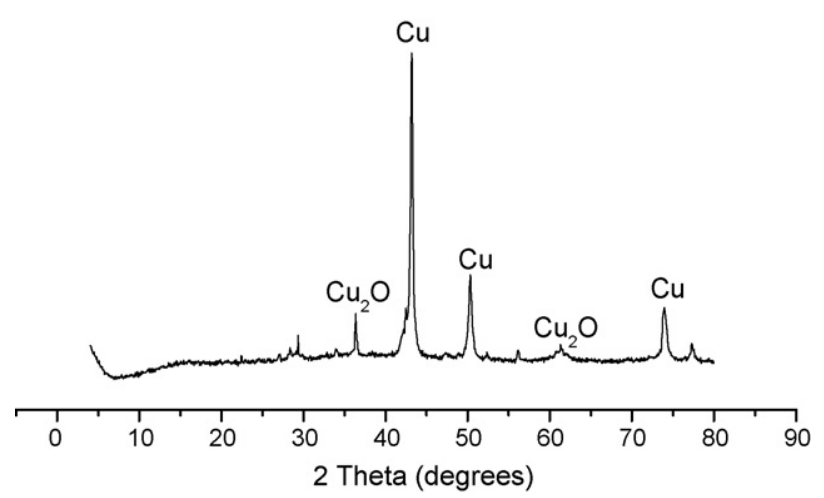

Fig. 8. X-ray diffraction patterns of $\mathrm{Cu}$ deposited on cathode.

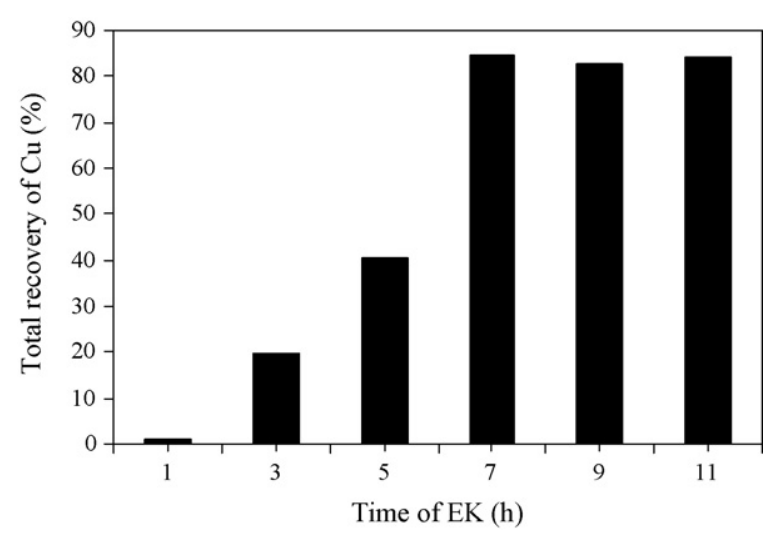

Fig. 9. Effect of EK time on total recovery yield of $\mathrm{Cu}$.

$11 \mathrm{~h}$ EK treatment (Fig. 5), and $89.4 \%$ of $\mathrm{Pb}$ was recovered while $66.3 \%$ concentrated in cathode compartment and $23.1 \%$ in anode compartment, whereas little $\mathrm{Pb}$ could be deposited on the cathode (Fig. 6). Although the highest total Cu recovery yield (about $84.7 \%$ ) was obtained at $7 \mathrm{~h}$, and that for $\mathrm{Pb}$ (about 90\%) at $9 \mathrm{~h}$ in the EK process, the highest deposition yield of Cu was obtained at $11 \mathrm{~h}$ (Fig. 5), where $\mathrm{Cu}$ (crystal properties can be seen in Fig. 8.) can be directly recovered. In Fig. 8, a weak characteristic peaks of $\mathrm{Cu}_{2} \mathrm{O}$ also can be observed, which could be attributed to the partial oxidation of $\mathrm{Cu}$ deposited on the cathode. Therefore, $11 \mathrm{~h}$ was performed in the EK process, where $89.4 \%$ of lead and $84.2 \%$ of copper were recovered, while $74 \%$ of $\mathrm{Cu}$ can be recovered as a precipitate on the cathode with a purity of $97.6 \%$ (Table 3 ).

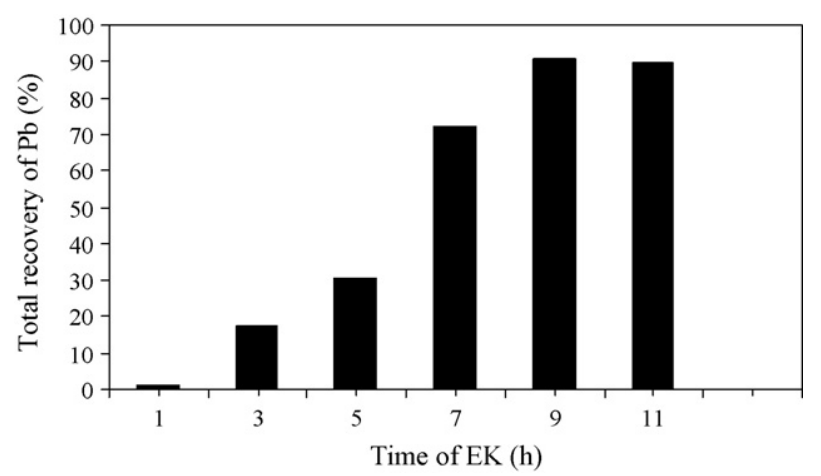

Fig. 10. Effect of EK time on total recovery yield of $\mathrm{Pb}$. 


\section{Conclusions}

The results of this study demonstrated that SCWO technique was efficient and benign as a pre-treatment to decompose the organic compounds of PCBs. In such a process, copper and lead were oxidized to $\mathrm{CuO}, \mathrm{Cu}_{2} \mathrm{O}$ and $\beta-\mathrm{PbO}_{2}$, and the loss of copper and lead was negligible under optimum condition: $60 \mathrm{~min}, 713 \mathrm{~K}, 30 \mathrm{MPa}$.

In the EK process with $1 \mathrm{M} \mathrm{HCl}$ as assisting agent, most copper migrated to the cathode compartment and deposited on the cathode, while lead moved towards either anode or cathode compartment, and little was deposited on electrodes. Hence it is feasible to effectively and separately recover copper and lead in the EK process. When $11 \mathrm{~h}$ treatment time and $20 \mathrm{~mA} / \mathrm{cm}^{2}$ constant current density were applied in the EK process, about $84.2 \%$ of copper was recovered in the cathode compartment, among which $74 \%$ deposited on cathode with a purity of $97.6 \%$, which can be directly reused in second industry. Meanwhile, $89.4 \%$ of lead was recovered as concentrated solutions in anode and cathode compartments.

\section{Acknowledgements}

This research was financially supported, in part, by the National Key Technology R\&D Program (2008BAC32B03) and the National Basic Research Program (2007CB407303) of China.

\section{References}

[1] U.S. Environmental Protection Agency, eCycling Homepage, http://www.epa. gov/epaoswer/hazwaste/recycle/ecycling/index.htm.

[2] N. Menad, B. Bjorkman, E.G. Allain, Combustion of plastics contained in electric and electronic scrap, Resour. Conserv. Recycl. 24 (1998) 65-85.

[3] Y. Li, J. Richardson, A. Walker, TCLP heavy metal leaching of personal computer components, J. Environ. Eng. 132 (2006) 497-504.

[4] K.S. Lin, H.P. Wang, Supercritical water oxidation of 2-chlorophenol catalyzed by $\mathrm{Cu}^{2+}$ cations and copper oxide clusters, Environ. Sci. Technol. 34 (22)(2000) 4849-4854.

[5] C.P. O'Brien, M.C. Thies, D.A. Bruce, Supercritical water oxidation of the PCB congener 2-chlorobiphenyl in methanol solutions: a kinetic analysis, Environ. Sci. Technol. 39 (17) (2005) 6839-6844.

[6] M. Modell, In Standard Handbook of Hazardous Waste Treatment and Disposal, McGraw-Hill, New York, 1989.

[7] R.W. Shaw, T.B. Brill, A.A. Clifford, Supercritical water: a medium for chemistry, Chem. Eng. News 69 (1991) 26-39.
[8] H. Tagaya, Y. Shibasaki, C.K.J. Kadokawa, B. Hatano, Decomposition reactions of epoxy resin and polyetheretherketone resin in sub- and supercritical water, J. Mater. Cycles. Waste. Manag. 6 (2004) 1-5.

[9] Y. Nagai, R.L. Smith, H. Inomata, Direct observation of polyvinylchloride degradation in water at temperatures up to $500{ }^{\circ} \mathrm{C}$ and at pressures up to $700 \mathrm{MPa}$, J. Appl. Polym. Sci. 106 (2007) 1075-1086.

[10] Y.-C. Chien, H.P. Wang, K.-S. Lin, Y.W. Yang, Oxidation of printed circuit board wastes in supercritical water, Wat. Res. 34 (17) (2000) 4279-4283.

[11] Z. Fang, S.-K. Xu, J.A. Kozinski, Behavior of metals during combustion of industrial organic wastes in supercritical water, Ind. Eng. Chem. Res. 39 (2000) 4536-4542.

[12] L.M. Ottosen, H.K. Hansen, A. Ribeiro, A. Villumsen, Removal of $\mathrm{Cu}, \mathrm{Pb}$ and $\mathrm{Zn}$ in an applied electric field in calcareous and non-calcareous soils, J. Hazard. Mater. B 85 (2001) 291-299.

[13] A. Altin, M. Degirmenci, Lead (II) removal from natural soils by enhanced electrokinetic remediation, Sci. Tot. Environ. 337 (2005) 1-10.

[14] M. Castellote, C. Andrade, C. Alonso, Nondestructive decontamination of mortar and concrete by electro-kinetic methods: application to the extraction of radioactive heavy metals, Environ. Sci. Technol. 36 (2002) 2256-2261.

[15] D.E. Akretche, Influence of the solid nature in the efficiency of an electrokinetic process, Desalination 147 (2002) 381-385.

[16] G. Traina, L. Morselli, G.P. Adorno, Electrokinetic remediation of bottom ash from municipal solid waste incinerator, Electrochim. Acta 52 (2007) 3380-3385.

[17] M.Y. Yu, H.P. Wang, C.Y. Chen, Recovery of zinc in phosphor wastes via electrokinetic treatments, J. Electron Spectrosc. Relat. Phenom. 156-158 (2007) 211-213.

[18] K. Popov, I. Glazkova, V. Yachmenev, Electrokinetic remediation of concrete: effect of chelating agents, Environ. Pollut. 153 (2008) 22-28.

[19] A. Giannis, E. Gidarakos, Washing enhanced electrokinetic remediation for removal of cadmium from real contaminated soil, J. Hazard. Mater. B70 (2005) $165-175$.

[20] N. Sabba, D.E. Akretche, Use of membrane in copper hydrometallurgy, Desalination 193 (2006) 422-425.

[21] N. Sabba, D.E. Akretche, Selective leaching of a copper ore by an electromembrane process using ammonia solutions, Miner. Eng. 19 (2006) 123-129.

[22] P. Guillaume, N. Leclerc, F. Lapicque, Electroleaching and electrodeposition of zinc in a single-cell process for the treatment of solid waste, J. Hazard. Mater. 152 (2008) 85-92.

[23] T. Oishi, K. Koyama, S. Alam, Recovery of high purity copper cathode from printed circuit boards using ammoniacal sulfate or chloride solutions, Hydrometallurgy 89 (2007) 82-88.

[24] C. Fromonteil, P. Bardelle, F. Cansell, Hydrolysis and oxidation of an epoxy resin in sub- and supercritical water, Ind. Eng. Chem. Res. 39 (2000) 922-925.

[25] A. Martell, Critical Stability Constants: Inorganic Complexes, Plenum Press, New York, 1976.

[26] G.M. Nystroem, A.J. Pedersen, L.M. Ottosen, The use of desorbing agents in electrodialytic remediation of harbour sediment, Sci. Tot. Environ. 357 (2006) 25-37. 